\title{
Nitrogen Supplementation of Corn Silages. 1. Effects on Feed Intake and Milk Production of Dairy Cows
}

\author{
A. R. J. Cabrita, ${ }^{\star} † \ddagger$ A. J. M. Fonseca, ${ }^{\star} \ddagger$ R. J. Dewhurst,§ C. V. P. Sampaio, \\ M. F. S. Miranda, „| G. N. S. Sousa, ${ }^{\star} \dagger$ I. M. F. Miranda, ${ }^{\star} \dagger$ and E. Gomes \\ ${ }^{*}$ Centro de Estudos de Ciência Animal do Instituto \\ de Ciências e Tecnologias Agrárias e Agro-Alimentares, \\ †Faculdade de Ciências and \\ łInstituto de Ciências Biomédicas de Abel Salazar, Universidade do Porto, \\ Campus Agrário de Vairão, 4485-661 Vairão VC, Portugal, \\ §Institute of Grassland and Environmental Research, Plas Gogerddan, \\ Aberystwyth, Ceredigion SY23 3EB, U.K., and \\ |Divisão de Leite e Lacticínios, Estação Experimental, \\ Direcção Regional de Agricultura do Entre-Douro e Minho, \\ 4594-909 Paços de Ferreira, Portugal
}

\section{ABSTRACT}

Feed intake and milk production responses to $\mathrm{N}$ supplementation of corn silage-based diets were measured in three $3 \times 3$ Latin square experiments. In each experiment, 9 Holstein cows received total mixed rations (TMR), based on corn silage. In Exp. 1, midlactation cows were used to study effects of diets with different ratios of effective rumen-degradable protein (ERDP; $g$ ) to fermentable metabolizable energy (FME; MJ), providing a large deficiency (RL), a slight deficiency (RM), and a slight excess $(\mathrm{RH})$ in relation to the target level of $11 \mathrm{~g}$ of ERDP/MJ of FME, respectively, for lactating cows. Diets were formulated to be isoenergetic, and to satisfy the metabolizable protein requirements. In Exp. 2 , early-lactation cows were used to evaluate effects of different proportions of quickly and slowly rumendegradable protein (RDP), achieved by replacing soybean meal with urea in the concentrates $(0,0.5$, and $1 \%$ urea). Experiment 3 investigated effects of synchronizing the availability of FME and ERDP in the rumen. Midlactation cows received a diet containing, on a dry matter (DM) basis, $45 \%$ corn silage, $5 \%$ ryegrass hay, $35 \%$ energy-rich concentrate, and $15 \%$ protein-rich concentrate (crude protein: $38 \%$ of DM; urea: $2 \%$ of DM). The protein-rich concentrate was fed either once (D1) or twice (D2) per day before the meal, or included in the TMR (DU). Treatment RL led to lower DM intake and milk yield, but higher milk production efficiency; there were no significant differences between treatments RM and RH. There were no significant treatment effects on DM intake, milk yield, or milk composition

Received April 7, 2003

Accepted July 8, 2003.

Corresponding author: A. R. J. Cabrita; e-mail address: rita. cabrita@mail.icav.up.pt. in Exp. 2. Manipulating rumen synchrony by altering the timing of feeding affected milk yields, with D1 cows producing significantly less than D2 and DU cows, which were similar. The amount of ERDP in the diet should be matched to the amount of fermentable energy available to maximize intake, milk yields, and the conversion of feed $\mathrm{N}$ into milk protein. However, this study showed only small benefits to altering the diurnal pattern of supply of RDP and FME, and only with extreme feeding strategies that would not be used in practice. Urine volume increased in response to increased or unbalanced protein supply. Analysis of the allantoin:creatinine ratio in spot samples of urine was not useful in identifying predicted differences in microbial protein yield from the rumen.

(Key words: corn silage, dairy cow, nitrogen supplementation, rumen synchrony)

Abbreviation key: $\mathbf{A} / \mathbf{c}=$ allantoin/creatinine; $\mathbf{D} 1=$ protein-rich concentrate fed once a d before the a.m. meal; $\mathbf{D 2}=$ protein-rich concentrate fed twice a $d$ before both meals; $\mathbf{D U}=$ protein-rich concentrate given as a TMR with the basal diet; ERDP = effective rumendegradable protein; FME = fermentable metabolizable energy; QDP = quickly rumen-degradable protein; $\mathbf{R H}$ = diet with a slight excess of ERDP in relation to FME; $\mathbf{R L}=$ diet with a large deficiency of ERDP in relation to FME; RM = diet with a slight deficiency of ERDP in relation to FME; SDP = slowly rumen-degradable protein; U0 = concentrate with $0 \%$ urea; $\mathbf{U 5}=$ concentrate with $0.5 \%$ urea; $\mathbf{U 1 0}=$ concentrate with $1 \%$ urea

\section{INTRODUCTION}

Milk production systems in the coastal region of northern and central Portugal are normally based on corn silage, with protein requirements met mainly by 
using corn byproducts and soybean meal. Dairy producers tend to feed additional dietary CP to dairy cows to promote higher feed intake and milk production (Cressman et al., 1980; Christensen et al., 1993; Wu and Satter, 2000). However, excess dietary CP has also been related to $\mathrm{N}$ pollution of water resources (Tamminga, 1992), production of greenhouse gases (Dewhurst et al., 2001), and impaired fertility (McCormick et al., 1999). Nitrate pollution of water resources is a major concern in Portugal, with some important dairy areas located in delimited N pollution-vulnerable areas. Dairy farm effluents are responsible for a significant portion of the $\mathrm{N}$ excreted onto land and water resources. Furthermore, protein sources continue to be expensive feed ingredients, so improving the efficiency of use of dietary $\mathrm{CP}$ is important both for increasing profitability and reducing potential pollution of dairy farms.

Modern protein rationing systems for dairy cows (e.g., AFRC, 1993; NRC, 2001) involve feeding protein first to meet the requirements of rumen microbes (for RDP) and then supplying RUP to meet the metabolizable protein requirements of the cow. The U.K. system (AFRC, 1993) considers that quickly degraded protein (QDP), defined as CP that is washed out of Dacron bags immediately, is used less efficiently than slowly degraded protein (SDP). The U.K. system considers QDP to be used with $80 \%$ efficiency as RDP, and defines the term "effective RDP" (ERDP) as $80 \%$ of QDP plus $100 \%$ of SDP.

Maximizing the utilization of RDP and conversion into microbial protein is a key objective of protein feeding strategies. Increasing the efficiency of microbial protein synthesis in the rumen will increase the utilization of the nutrients supplied to the host animal and the supply of essential AA at a relatively lower cost than via an increase in dietary RUP. Earlier studies have shown the importance of balancing the supply of RDP to the availability of fermentable metabolizable energy (FME) (Mabjeesh et al., 1997; Casper et al., 1999). This study tested these relationships using the feeds that are commonly used in northern Portugal. Other workers have suggested that it may be important to optimize the diurnal patterns of supply of RDP and FME (the "synchrony concept"), in addition to balancing overall supply. The basic assumption of the synchrony concept is that a lack of synchrony between the rates at which energy and $\mathrm{N}$ become available to the microbes reduces the efficiency of microbial capture of $\mathrm{N}$ and results in inefficient use of ATP for microbial growth (Chamberlain and Choung, 1995).

It has been very difficult to evaluate the effects of rumen synchrony in feeding experiments because of confounding between diet ingredients and synchrony indices (Dewhurst et al., 2000). One approach is to ma- nipulate rumen synchrony by feeding the same diet overall, but manipulating the supply pattern of energyand protein-rich components within a day. The studies reported in this paper have evaluated effects of synchrony, both by manipulating diet ingredients (Exp. 2) and by manipulating the times at which different feed ingredients were given (Exp. 3).

Analysis of allantoin and creatinine in spot urine samples was used to investigate effects on microbial protein yield from the rumen. This technique assumes that purines leaving the rumen are essentially of microbial origin (McAllan, 1982) and that there is a positive relationship between purines leaving the rumen and excretion of their derivatives (mainly allantoin in cattle) in urine (Chen et al., 1990). Creatinine has been used as an internal marker of urinary output, based on the assumption of a relatively constant daily output in relation to body mass (De Groot and Aafjes, 1960). Dewhurst et al. (1996) suggested that the purine derivatives:creatinine ratio in spot urine samples has potential as a on-farm diagnostic of microbial CP supply.

\section{MATERIALS AND METHODS}

This series of experiments was conducted at the Dairy Unit of the Direcção Regional de Agricultura do EntreDouro e Minho of the Ministry of Agriculture (Paços de Ferreira, Portugal). This unit has approximately 50 milking cows with a mean 305-d lactation in 2000 of $8961 \mathrm{~kg}$.

\section{Experiment 1}

Six multiparous and three primiparous Holstein cows averaging $564 \mathrm{~kg}$ of BW (SD = 55.8), 149 DIM (SD = $13.0)$, and $29 \mathrm{~kg} / \mathrm{d}$ of milk (SD = 4.6) were blocked according to milk production and DIM into three groups of three cows each. Cows were randomly assigned to dietary treatment sequences in three $3 \times 3$ Latin squares. Each experimental period lasted for $4 \mathrm{wk}$, with measurements performed in the last $7 \mathrm{~d}$. The cows were kept in tie stalls with individual feed bins in an animal house, which was well ventilated and had continuous access to water. Diets contained (DM basis) approximately $40 \%$ corn silage, $5 \%$ coarsely chopped ryegrass hay, and 55\% concentrate. The whole-crop corn silage was prepared during late September 1999 without the use of a silage additive. The three treatments were formulated, according to AFRC (1993), to be isoenergetic, satisfy metabolizable protein requirements, and to differ in the ratio of ERDP:FME, providing a large deficiency (RL), a slight deficiency (RM), and a slight excess (RH) of ERDP in relation to the target level (11 $\mathrm{g}$ of ERDP/MJ of FME) suggested in the U.K. system 
Table 1. Ingredient composition (\% as mixed) of the concentrates. ${ }^{1}$

\begin{tabular}{|c|c|c|c|c|c|c|c|c|}
\hline \multirow[b]{2}{*}{ Item } & \multicolumn{3}{|c|}{ Experiment 1} & \multicolumn{3}{|c|}{ Experiment 2} & \multicolumn{2}{|c|}{ Experiment 3} \\
\hline & $\mathrm{RL}^{2}$ & $\mathrm{RM}^{2}$ & $\mathrm{RH}^{2}$ & $\mathrm{U}^{3}$ & $\mathrm{U} 5^{3}$ & $\mathrm{U} 10^{3}$ & $\mathrm{CEn}^{4}$ & $\operatorname{CPr}^{4}$ \\
\hline Wheat grain & 20.0 & 17.0 & 23.0 & 23.0 & 21.0 & 21.0 & 35.0 & $\ldots$ \\
\hline Corn gluten feed & 14.1 & 31.8 & 5.5 & 38.0 & 45.0 & 47.0 & 40.0 & \\
\hline Corn gluten meal & 7.0 & $\ldots$ & $\ldots$ & $\ldots$ & & $\ldots$ & & \\
\hline Citrus pulp & 33.0 & 5.5 & 4.4 & 4.0 & 4.5 & 6.0 & 13.5 & . \\
\hline Rapeseed meal & 4.0 & 18.0 & 25.0 & & & & $\ldots$ & \\
\hline Soybean meal, $44 \% \mathrm{CP}$ & 7.5 & 5.0 & 12.5 & 25.0 & 19.0 & 15.0 & $\ldots$ & 38.0 \\
\hline Sunflower meal & 7.5 & 13.0 & 19.0 & $\ldots$ & & $\ldots$ & $\ldots$ & 57.0 \\
\hline Molasses & 3.0 & 3.0 & 3.0 & 3.0 & 3.0 & 3.0 & 3.0 & 3.0 \\
\hline Hydrogenated fat ${ }^{5}$ & 0.6 & 3.0 & 4.0 & 3.0 & 3.0 & 3.0 & 3.0 & \\
\hline Urea & $\ldots$ & $\ldots$ & $\cdots$ & $\ldots$ & 0.5 & 1.0 & & 2.0 \\
\hline $\mathrm{CaCO}_{3}$ powder & $\ldots$ & 1.5 & 1.4 & 1.5 & 1.5 & 1.5 & 1.7 & $\ldots$ \\
\hline Dicalcium phosphate & 1.1 & $\ldots$ & & 0.3 & 0.3 & 0.3 & 0.8 & $\ldots$ \\
\hline Salt & 0.5 & 0.5 & 0.5 & 0.5 & 0.5 & 0.5 & 0.7 & $\ldots$ \\
\hline Sodium bicarbonate & 0.85 & 0.85 & 0.85 & 0.85 & 0.85 & 0.85 & 1.20 & $\ldots$ \\
\hline Magnesium oxide & 0.65 & 0.65 & 0.65 & 0.65 & 0.65 & 0.65 & 0.80 & \\
\hline Mineral and vitamin premix ${ }^{6}$ & 0.2 & 0.2 & 0.2 & 0.2 & 0.2 & 0.2 & 0.3 & \\
\hline
\end{tabular}

${ }^{1}$ For each experiment, concentrates were prepared in a single batch by SODOL, Sociedade Descascadora Ovarense, Ltd., Ovar, Portugal.

${ }^{2}$ Concentrates are named according to the effective RDP:fermentable metabolizable energy ratio of the diet: RL, RM, and RH provided a large deficiency, a slight deficiency, and a slight excess, respectively.

${ }^{3}$ Concentrates are named according to their urea content: U0 $=0 \%, \mathrm{U} 5=0.5 \%$, and U10 $=1.0 \%$.

${ }^{4}$ Concentrates are named according to the main nutrients supplied: $\mathrm{CEn}=$ energy-rich nutrients and $\mathrm{CPr}$ $=\mathrm{N}$-rich nutrients.

${ }^{5}$ Hydrogenated palm fatty acids (Vetagrialimentar SA, Cantanhede, Portugal).

${ }^{6}$ Contained 7,500,000 IU/kg of vitamin A; 1,250,000 IU/kg of vitamin $\mathrm{D}_{3} ; 20,000 \mathrm{mg} / \mathrm{kg}$ of vitamin E; 200 $\mathrm{mg} / \mathrm{kg}$ of $\mathrm{Co} ; 1000 \mathrm{mg} / \mathrm{kg}$ of Cu; $25,000 \mathrm{mg} / \mathrm{kg}$ of $\mathrm{Fe} ; 385 \mathrm{mg} / \mathrm{kg}$ of I; $50,000 \mathrm{mg} / \mathrm{kg}$ of $\mathrm{Mg} ; 30,000 \mathrm{mg} / \mathrm{kg}$ of $\mathrm{Mn} ; 65 \mathrm{mg} / \mathrm{kg}$ of Se; and $20,000 \mathrm{mg} / \mathrm{kg}$ of $\mathrm{Zn}$.

(AFRC, 1993) for lactating cows. The different ERDP:FME ratios were achieved by altering the composition of the concentrates (Table 1). Diets were fed as TMR for ad libitum intake, with fresh feed offered twice each day (0830 and $1500 \mathrm{~h}$ ). The troughs were cleaned out each morning and orts were collected and weighed. Feed offered was adjusted each week to produce weigh backs of approximately $10 \%$ of amounts fed. Cows were milked twice daily at 0800 and $1730 \mathrm{~h}$.

Milk production was measured throughout the experimental period. Milk was sampled at both milkings on 2 consecutive days during the last week of each experimental period, and proportional composites were analyzed for fat, protein, and lactose (AOAC, 1990; Milkoscan 133, Foss Electric, Hillerød, Denmark). Samples of feces and urine were collected from each cow at 8-h intervals $(0800,1600$, and $2400 \mathrm{~h}$ ), on the same 2 consecutive days, respectively, for estimation of diet digestibility using acid-insoluble ash as an indigestible internal marker, and for urinary allantoin and creatinine concentrations analysis. When cows did not voluntarily urinate, even after stimulation of the vulva, urine collection was performed using a catheter. Blood samples were collected into heparinized tubes from the jugular vein of each cow at $3 \mathrm{~h}$ after the morning feeding. Samples were immediately centrifuged at $3500 \mathrm{rpm}$ for 10 min and the plasma stored at $-15^{\circ} \mathrm{C}$ prior to analysis for glucose, urea, albumin, and total proteins. Cows were weighed at the same time on the final day of each period. Maximal and minimal daily barn temperatures were recorded throughout the experiment.

\section{Experiment 2}

Six multiparous and three primiparous Holstein cows averaging $550 \mathrm{~kg}$ of $\mathrm{BW}(\mathrm{SD}=49.7), 63 \mathrm{DIM}(\mathrm{SD}=$ 31.3 ), and $34 \mathrm{~kg} / \mathrm{d}$ of milk (SD $=5.0$ ) were used. This experiment also used three $3 \times 3$ Latin squares with 4 wk periods and measurements performed in the last 7 $\mathrm{d}$. Three isoenergetic and iso-ERDP diets, based on corn silage, were formulated to differ in the ratio of QDP:SDP. The different QDP:SDP ratios were achieved by replacing soybean meal with urea in the concentrates $(0,0.5$, and $1.0 \%$ urea for treatments U0, U5, and U10, respectively) (Table 1). The whole-crop corn silage was prepared during late September 2000 without the use of a silage additive. Assignment of cows to treatments and management were the same as in Exp. 1 . The TMR differed in that $60 \%$ of the DM was from concentrate, $35 \%$ from corn silage, and 5\% from ryegrass hay, and that fresh feed was offered at 0800 and $1530 \mathrm{~h}$ each day. Cows were milked twice daily at 0700 
and $1630 \mathrm{~h}$. Feces and urine were collected from each cow at 0600,1400 , and $2200 \mathrm{~h}$ over 2 consecutive days. Blood samples were taken $4 \mathrm{~h}$ after the morning feeding.

\section{Experiment 3}

This experiment was carried out simultaneously with Exp. 2, using the same forages. This experiment also used three $3 \times 3$ Latin squares with 4 -wk periods. Three multiparous and six primiparous Holstein cows averaging $542 \mathrm{~kg}$ of BW (SD = 37.4), 127 DIM $(\mathrm{SD}=31.0)$, and $29 \mathrm{~kg} / \mathrm{d}$ of milk (SD = 5.9) were used. To avoid confounding between rumen synchrony and diet ingredients, all treatments were based on a single diet, which contained (on a DM basis) corn silage (45\%), ryegrass hay (5\%), energy-rich concentrate $(35 \%)$, and proteinrich concentrate (15\%). Details of the concentrate composition are given in Table 1. Feed was offered at the same times as Exp. 2, with the protein-rich concentrate either fed once (before the morning meal; D1) or twice (before both meals; D2) a day before the meal, or as a TMR given with the basal diet (DU). Assignment of cows to treatments and management was as described for Exp. 2, except that blood samples were collected immediately before and $4 \mathrm{~h}$ after the morning feeding.

\section{In Sacco Feed Degradability}

Two nonlactating Holstein cows (480 and $575 \mathrm{~kg}$ of BW) fitted with rumen cannulae (10 cm diameter; Bar Diamond Inc., Parma, ID) were used to measure rumen degradability of feeds. The cows were fed a diet comprising (DM basis) $45 \%$ corn silage (DM: $28 \%$; NDF: $53 \%$ of DM; starch: $24 \%$ of DM), $5 \%$ ryegrass hay (CP: $8 \%$ of DM; NDF: $58 \%$ of DM), and $50 \%$ commercial concentrate (CP: $24 \%$ of DM; starch: $22 \%$ of DM; urea: $0.9 \%$ of DM) at $1.2 \times$ maintenance (AFRC, 1993). The cows were kept in individual tie stalls with individual feed bins in an animal house, which was well ventilated and had continuous access to water. Diets were fed as TMR with fresh feed offered twice each day (0930 and 1730 h). The nylon bag technique (Ørskov et al., 1980) was used to measure the DM and $\mathrm{N}$ degradation of feeds in the rumen. Nylon bags $(10 \times 20 \mathrm{~cm}$; Bar Diamond Inc.) containing $4 \mathrm{~g}$ of forages that had been ground through a 4-mm screen or the concentrates as-fed were incubated in the rumen of each cow for $12 \mathrm{~h}$ immediately after the morning feed on two nonconsecutive days. In total, there were 8 replicates for each feed sample (2 cows $\times 2 \mathrm{~d} \times 2$ bags). Immediately after removal from the rumen, the bags were washed in cold water and frozen at $-15^{\circ} \mathrm{C}$. At the end of the collections, they were unfrozen and washed together with the time-zero bags (not incubated in the rumen) in a washing machine for $40 \mathrm{~min}$ at $40^{\circ} \mathrm{C}$ and then dried at $65^{\circ} \mathrm{C}$ for $24 \mathrm{~h}$. Dried residues were analyzed for $\mathrm{N}$ content according to the Kjeldahl method (AOAC, 1990).

\section{Chemical Analysis}

Samples of corn silage, ryegrass hay, concentrates, and orts were sampled daily, and after oven DM determination $\left(65^{\circ} \mathrm{C}, 48 \mathrm{~h}\right)$, were composited over the recording week of each experimental period and submitted for chemical analysis. Ground samples $(1 \mathrm{~mm})$ were analyzed for ash and Kjeldahl N (AOAC, 1990). Crude protein was calculated as Kjeldahl $\mathrm{N} \times 6.25$. Neutral detergent fiber, $\mathrm{ADF}$, and acid detergent lignin were determined as described by Robertson and Van Soest (1981). Ether extract was determined by extracting the sample with petroleum ether using a Gerhardt Soxtherm 2000 Automatic (AOAC, 1990). Total sugars, P, $\mathrm{Ca}$, and concentrates urea were determined by official Portuguese standard methods (Norma Portuguesa1785, 1986; Norma Portuguesa-873, 1997; Norma Portuguesa-1786, 1985; and Norma Portuguesa-3255, 1986, respectively). Modified ADF content of corn silages and ryegrass hays was determined by the method described by Ministry of Agriculture, Fisheries and Food (1986). Metabolizable energy content of corn silages and ryegrass hays was estimated from modified ADF content according to Givens (1990) and Moss and Givens (1990), respectively. The metabolizable energy content of concentrates was estimated according to Eq. [E3] from Thomas et al. (1988). Acid-insoluble ash was determined as described by the official standard method (Norma Portuguesa-2971, 1985). Starch was determined from $0.5-\mathrm{mm}$ samples by the method described by Solomonsson et al. (1984). Urinary allantoin and creatinine concentrations were determined by HPLC as described by Dewhurst et al. (1996). Jugular plasma was analyzed for glucose, urea, albumin, and total proteins (Automated chemistry analyzer, Olympus, AUG40, Melville, NY) by enzymatic (glucose-oxidase and urease) and colorimetric (bromocresol and biuret) methods as described by Bauer (1982).

\section{Statistical Analysis}

One cow from Exp. 1 had a displaced abomasum; therefore, all related results were excluded from the analysis. Results were excluded from two cow periods in Exp. 2 (one cow had a digestive upset in period 1 and one cow was injured in period 3). One cow was removed from Exp. 3 because of chronic mastitis. In 
Table 2. Chemical analysis (\% of DM, unless stated otherwise), metabolizable energy (ME; MJ/kg DM) content, and 0- and 12-h CP degradability in sacco (CPDeg; \%CP) of the feeds used in this work.

\begin{tabular}{|c|c|c|c|c|c|c|c|c|c|c|c|c|}
\hline \multirow[b]{2}{*}{ Item } & \multicolumn{5}{|c|}{ Experiment 1} & \multicolumn{2}{|c|}{$\begin{array}{c}\text { Experiments } \\
2 \text { and } 3\end{array}$} & \multicolumn{3}{|c|}{ Experiment 2} & \multicolumn{2}{|c|}{ Experiment 3} \\
\hline & $\mathrm{CS}^{1}$ & $\mathrm{RH}^{2}$ & $\mathrm{RL}^{3}$ & $\mathrm{RM}^{3}$ & $\mathrm{RH}^{3}$ & $\mathrm{CS}^{1}$ & $\mathrm{RH}^{2}$ & $\mathrm{U}^{4}$ & $\mathrm{U} 5^{4}$ & $\mathrm{U} 10^{4}$ & $\mathrm{CEn}^{5}$ & $\mathrm{CPr}^{5}$ \\
\hline $\mathrm{DM}, \%$ & 32.7 & 88.6 & 89.1 & 89.9 & 89.8 & 32.6 & 83.7 & 90.5 & 90.7 & 90.9 & 90.8 & 90.6 \\
\hline Ash & 4.3 & 4.7 & 8.6 & 10.0 & 9.7 & 3.6 & 6.0 & 9.4 & 9.8 & 9.9 & 10.0 & 7.7 \\
\hline $\mathrm{CP}$ & 7.2 & 6.5 & 19.5 & 22.3 & 25.3 & 7.4 & 6.0 & 23.0 & 22.8 & 24.2 & 15.1 & 37.7 \\
\hline $\mathrm{EE}^{6}$ & 3.4 & 1.2 & 3.4 & 4.3 & 4.4 & 3.2 & 1.4 & 4.5 & 4.6 & 4.5 & 4.9 & 2.7 \\
\hline $\mathrm{NDF}^{7}$ & 46.5 & 70.0 & 24.7 & 29.9 & 26.1 & 42.7 & 66.4 & 21.5 & 23.5 & 23.3 & 22.5 & 30.0 \\
\hline $\mathrm{ADF}$ & 26.5 & 39.3 & 11.0 & 12.8 & 13.9 & 23.2 & 40.8 & 8.8 & 8.4 & 8.9 & 9.1 & 20.4 \\
\hline $\mathrm{ADL}^{8}$ & 3.9 & 7.4 & 4.2 & 4.8 & 5.2 & 3.4 & 6.3 & 2.5 & 2.3 & 2.8 & 2.4 & 5.9 \\
\hline Sugars & 0.8 & 8.4 & 13.6 & 8.8 & 9.4 & 0.9 & 13.8 & 7.4 & 7.5 & 6.7 & 8.3 & 9.5 \\
\hline Starch & 28.3 & $\mathrm{ND}^{9}$ & 16.0 & 15.4 & 14.3 & 33.8 & ND & 24.3 & 23.1 & 24.3 & 26.2 & 4.3 \\
\hline Urea & ND & ND & ND & ND & ND & ND & ND & ND & 0.5 & 1.0 & ND & 2.0 \\
\hline $\mathrm{P}$ & 0.20 & 0.14 & 0.67 & 0.74 & 0.72 & 0.25 & 0.18 & 0.74 & 0.79 & 0.76 & 0.71 & 0.81 \\
\hline $\mathrm{Ca}$ & 0.21 & 0.32 & 1.41 & 1.45 & 1.48 & 0.21 & 0.39 & 1.18 & 1.28 & 1.24 & 1.59 & 0.62 \\
\hline $\mathrm{ME}$ & 10.4 & 7.7 & 12.6 & 12.1 & 12.1 & 10.7 & 8.4 & 12.9 & 12.7 & 12.7 & 12.7 & 11.4 \\
\hline 0-h CPDeg & 55.6 & 20.8 & 43.9 & 57.8 & 57.4 & 55.0 & 25.0 & 57.8 & 61.5 & 65.0 & 69.4 & 63.2 \\
\hline 12-h CPDeg & 56.6 & 28.1 & 58.4 & 78.8 & 78.2 & 60.5 & 25.9 & 76.4 & 77.4 & 81.4 & 81.2 & 81.6 \\
\hline
\end{tabular}

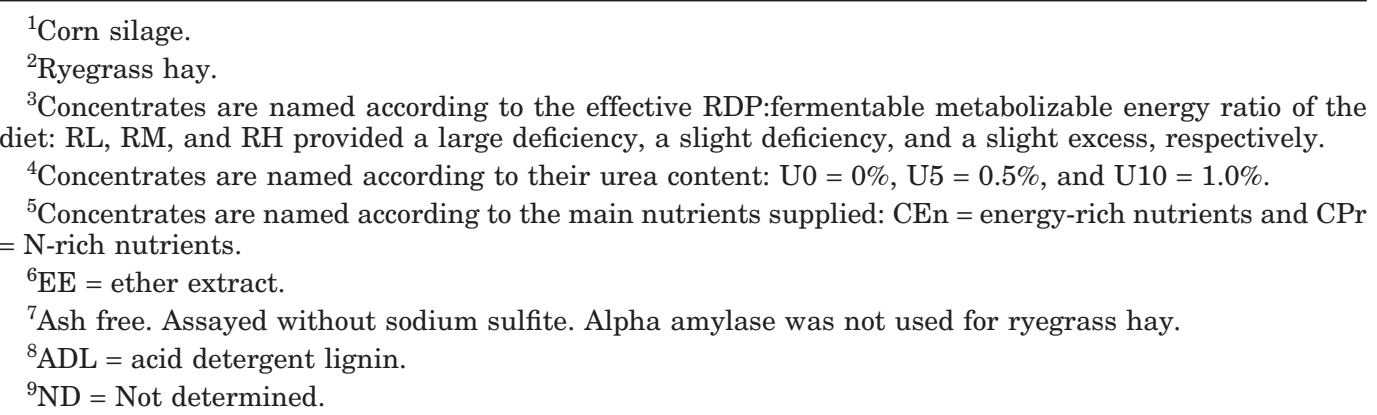

addition, data from three cow-periods (one in each period) were excluded for reasons that were not directly related to treatments (two cases of mastitis; one cow consuming the wrong diet).

All data were subjected to least squares ANOVA for three $3 \times 3$ Latin squares (Steel and Torrie, 1980) using the GLM procedure of SAS (Version 8e, SAS Inst. Inc., Cary, NC). The model included square, cow within square, period within square, dietary treatment, and residual error. For the analysis of urinary allantoin and creatinine concentrations (all experiments) and of plasma metabolites (Exp. 3), the model also initially included sampling time and the dietary treatment $x$ sampling time interaction. The dietary treatment $x$ sampling time interaction was never significant $(P>$ 0.05 ) for urinary measurements and was removed from the model. When differences were significant the least squares difference test (Steel and Torrie, 1980) was used to compare means.

\section{RESULTS}

Mean maximal and minimal daily barn temperatures were $27.1^{\circ} \mathrm{C}(\mathrm{SD}=5.41)$ and $14.1^{\circ} \mathrm{C}(\mathrm{SD}=2.38)$ for Exp. 1 , and $13.7^{\circ} \mathrm{C}(\mathrm{SD}=2.10)$ and $9.3^{\circ} \mathrm{C}(\mathrm{SD}=1.88)$ for Exp. 2 and 3 , respectively.
The chemical composition of the corn silages, ryegrass hays, and concentrates are given in Table 2 . The corn silage used in Exp. 2 and 3 had a higher starch content than that used in Exp. 1. The CP contents of the concentrates used in Exp. 1 closely matched the values from the formulation, and concentrate RL had a high total sugar content as a result of the high inclusion of citrus pulp. The concentrates used in Exp. 2 showed urea contents as formulated. In Exp. 3, the energy-rich concentrate contained (percentage of DM) $15.1 \% \mathrm{CP}$ and $26.2 \%$ starch, and the protein-rich concentrate had $37.7 \% \mathrm{CP}$ and $2 \%$ urea. Table 3 shows the composition of diets as consumed. The dietary CP level in Exp. 1 increased with the increase in ERDP:FME ratio. The composition of the diets used in Exp. 2 was very similar; all of these diets and also the diet used in Exp. 3 had a higher starch content than the diets used in Exp. 1. Table 4 presents the calculated metabolizable energy, FME, ERDP and RUP contents, and ERDP:FME ratio of each diet. The ERDP:FME ratios, calculated according to AFRC (1993) and based on the determined CP degradability in sacco values of feeds for Exp. 1, were 6.7, 10.1, and $11.2 \mathrm{~g}$ of ERDP/MJ of FME for diets RL, RM, and RH, respectively; and for Exp. 2 were 10.0, 10.1, and $11.1 \mathrm{~g}$ of ERDP/MJ of FME 
Table 3. Composition of diets as consumed after correction for orts (\% of DM) from different dietary treatments. SD is given in parentheses.

\begin{tabular}{|c|c|c|c|c|c|c|c|}
\hline Item & $\mathrm{n}$ & Ash & $\mathrm{CP}$ & $\mathrm{NDF}$ & $\mathrm{ADF}$ & $\mathrm{ADL}^{4}$ & Starch \\
\hline \multicolumn{8}{|c|}{ Experiment 1} \\
\hline $\mathrm{RL}^{1}$ & 8 & $6.6(0.20)$ & $14.0(0.46)$ & $34.7(1.55)$ & $18.1(0.48)$ & $4.3(0.26)$ & $20.8(1.90)$ \\
\hline $\mathrm{RM}^{1}$ & 8 & $7.5(0.15)$ & $15.7(0.37)$ & $37.9(0.71)$ & $19.1(0.44)$ & $4.6(0.13)$ & $20.0(1.58$ \\
\hline $\mathrm{RH}^{1}$ & 8 & $7.2(0.17)$ & $17.5(0.12)$ & 35.5 (1.13) & $19.5(0.32)$ & $4.8(0.23)$ & $19.6(1.72)$ \\
\hline \multicolumn{8}{|c|}{ Experiment 2} \\
\hline $\mathrm{U}^{2}$ & 9 & $7.2(0.04)$ & $16.8(0.44)$ & $31.0(0.24)$ & $15.3(0.98)$ & $3.0(0.64)$ & $26.7(0.25)$ \\
\hline $\mathrm{U}^{2}$ & 9 & $7.5(0.12)$ & $16.7(0.33)$ & $32.0(0.50)$ & $14.8(0.62)$ & $2.8(0.30)$ & $26.3(0.56)$ \\
\hline $\mathrm{U} 10^{2}$ & 7 & $7.5(0.17)$ & $17.5(0.64)$ & $31.9(0.56)$ & $15.2(0.52)$ & $3.1(0.29)$ & $26.7(0.40)$ \\
\hline \multicolumn{8}{|c|}{ Experiment 3} \\
\hline $\mathrm{DU}^{3}$ & 7 & $6.5(0.16)$ & $14.5(0.38)$ & $34.2(0.96)$ & $18.2(0.82)$ & $3.4(0.23)$ & $25.9(0.33)$ \\
\hline $\mathrm{D} 2^{3}$ & 7 & $6.5(0.15)$ & $14.4(0.34)$ & $34.4(0.79)$ & $18.3(0.75)$ & $3.5(0.16)$ & $25.8(0.47)$ \\
\hline $\mathrm{D} 1^{3}$ & 7 & $7.2(1.56)$ & $14.5(0.47)$ & 34.2 (1.04) & $18.0(1.09)$ & $3.4(0.19)$ & $26.1(0.49)$ \\
\hline
\end{tabular}

${ }^{1}$ Diets are named according to the effective RDP:fermentable metabolizable energy ratio of the diet: RL, $\mathrm{RM}$, and RH provided a large deficiency, a slight deficiency, and a slight excess, respectively.

${ }^{2}$ Concentrates are named according to their urea content: $\mathrm{U} 0=0 \%, \mathrm{U} 5=0.5 \%$, and $\mathrm{U} 10=1.0 \%$.

${ }^{3}$ Treatments are named according to the mode of distribution of the protein-rich concentrate: DU $=$ as a TMR with the basal diet; D2 = in two meals, immediately before the distribution of the basal diet; and D1 $=$ in one meal, immediately before the distribution of the morning meal.

${ }^{4} \mathrm{ADL}=$ acid detergent lignin.

for diets U0, U5, and U10, respectively. In Exp. 3, the diet had a ERDP:FME ratio of $9.3 \mathrm{~g} / \mathrm{MJ}$.

Effects on feed intake, diet digestibility, milk production, and milk composition are presented in Table 5. Diet RL led to significantly lower DMI and milk yield than RM and RH. The efficiency of utilization of dietary CP for milk protein synthesis was significantly higher with diet RL, with no differences between $\mathrm{RM}$ and $\mathrm{RH}$. In Exp. 2, there were no treatment effects, except for

Table 4. Calculated metabolizable energy (ME; MJ/kg DM), fermentable metabolizable energy (FME; MJ/kg DM), effective RDP (ERDP; g/kg DM), and RUP (g/kg DM) contents, and ERDP:FME (g/ $\mathrm{MJ})$ ratio of diets from different dietary treatments.

\begin{tabular}{lrrrrr}
\hline Item & ME & FME $^{1}$ & ERDP $^{2}$ & RUP $^{3}$ & ERDP:FME \\
\hline Experiment 1 & & & & & \\
RL $^{4}$ & 11.4 & 9.9 & 66.3 & 59.2 & 6.7 \\
RM $^{4}$ & 11.2 & 9.4 & 95.1 & 40.9 & 10.1 \\
RH $^{4}$ & 11.2 & 9.4 & 105.3 & 45.2 & 11.2 \\
Experiment 2 & & & & & \\
U0 $^{5}$ & 11.9 & 10.1 & 101.2 & 45.4 & 10.0 \\
U5 $^{5}$ & 11.8 & 10.0 & 101.3 & 43.2 & 10.1 \\
U10 & 11.7 & 10.0 & 111.3 & 39.5 & 11.1 \\
Experiment 3 & 11.3 & 9.6 & 88.9 & 35.7 & 9.3 \\
\hline
\end{tabular}

${ }^{1}$ Calculated according to AFRC (1993)

${ }^{2}$ According to AFRC (1993), assuming quickly degradable protein (QDP) equals 0 -h CP degradability $\times \mathrm{CP}$, and slowly degradable protein (SDP) equals (12-h CP degradability -0 -h CP degradability) $\times$ $\mathrm{CP}$; calculated as $0.8 \times \mathrm{QDP}+\mathrm{SDP}$.

${ }^{3}$ Calculated as $\mathrm{CP}-(\mathrm{QDP}+\mathrm{SDP})$.

${ }^{4}$ Diets are named according to the ERDP:FME ratio of the diet: $\mathrm{RL}, \mathrm{RM}$, and $\mathrm{RH}$ provided a large deficiency, a slight deficiency, and a slight excess, respectively.

${ }^{5}$ Diets are named according to the urea content of the concentrates: $\mathrm{U} 0=0 \%, \mathrm{U} 5=0.5 \%$, and $\mathrm{U} 10=1.0 \%$. the efficiency of utilization of CP of diet for milk protein synthesis, which was significantly lower for diet U10. In Exp. 3, the cows that received all of their protein concentrate in a single meal (D1) produced less milk than the other cows (D2 and DU).

Allantoin and creatinine concentrations and allantoin/creatinine ratios $(\mathbf{A} / \mathbf{c})$ in spot urine samples, as well as estimated microbial CP supply according AFRC (1993), are given in Table 6 . The concentrations of both allantoin and creatinine were significantly higher for the low-ERDP:FME diet in Exp. 1. However, urinary $\mathrm{A} / \mathrm{c}$ was not significantly affected by diet. Sampling time did not affect any of the urine measurements in Exp. 1. Urinary concentrations of allantoin and the $\mathrm{A} / \mathrm{c}$ ratio were significantly lower for diet U5 in Exp. 2, with no effect on creatinine concentration. Sampling time affected all of the urine measurements in Exp. 2 and 3 , with the exception of urinary allantoin concentration. In Exp. 3, dietary treatment only significantly affected the urinary creatinine concentration, which was lower for diet D1.

Plasma concentrations of glucose, urea, albumin, and total proteins are given in Table 7. Plasma urea concentrations increased significantly with the increase in ERDP:FME ratio in Exp. 1. The treatments used in Exp. 2 and 3 had little overall effect on concentrations of plasma metabolites. However, concentrations of glucose and urea of Exp. 3 were higher and lower, respectively, in plasma sampled before the morning meal vs. plasma sampled after the morning meal (a significant treatment $\times$ sampling time interaction effect for plasma urea). 
Table 5. Least squares means for feed intake, milk production, milk composition, and diet OM digestibility and BW from the different dietary treatments.

\begin{tabular}{|c|c|c|c|c|c|c|c|c|c|c|c|c|c|c|c|}
\hline \multirow[b]{2}{*}{ Item } & \multicolumn{3}{|c|}{ Experiment 1} & \multirow[b]{2}{*}{ SEM } & \multirow[b]{2}{*}{$P$} & \multicolumn{3}{|c|}{ Experiment 2} & \multirow[b]{2}{*}{ SEM } & \multirow[b]{2}{*}{$P$} & \multicolumn{3}{|c|}{ Experiment 3} & \multirow[b]{2}{*}{ SEM } & \multirow[b]{2}{*}{$P$} \\
\hline & $\mathrm{RL}^{1}$ & $\mathrm{RM}^{1}$ & $\mathrm{RH}^{1}$ & & & $\mathrm{U}^{2}$ & $\mathrm{U} 5^{2}$ & $\mathrm{U} 10^{2}$ & & & $\mathrm{DU}^{3}$ & $\mathrm{D} 2^{3}$ & $\mathrm{D} 1^{3}$ & & \\
\hline $\mathrm{n}$ & 8 & 8 & 8 & & & 9 & 9 & 7 & & & 7 & 7 & 7 & & \\
\hline Yield, kg/d & $27.6^{\mathrm{a}}$ & $30.1^{b}$ & $29.2^{\mathrm{b}}$ & 0.46 & $*$ & 37.3 & 36.9 & 36.3 & 0.71 & NS & $29.2^{\mathrm{a}}$ & $29.3^{\mathrm{a}}$ & $27.9^{\mathrm{b}}$ & 0.31 & $*$ \\
\hline $4 \% \mathrm{FCM}, \mathrm{kg} / \mathrm{d}$ & 26.4 & 27.5 & 28.6 & 0.65 & NS & 34.6 & 35.4 & 35.0 & 0.97 & NS & 27.1 & 27.5 & 25.6 & 0.53 & NS \\
\hline Fat, $\%$ & 3.72 & 3.46 & 3.88 & 0.140 & NS & 3.49 & 3.72 & 3.73 & 0.135 & NS & 3.43 & 3.58 & 3.43 & 0.123 & NS \\
\hline Fat, kg/d & 1.02 & 1.03 & 1.13 & 0.039 & NS & 1.31 & 1.38 & 1.37 & 0.055 & NS & 1.02 & 1.05 & 0.96 & 0.035 & NS \\
\hline Protein, kg/d & 0.92 & 0.98 & 0.97 & 0.017 & $\dagger$ & 1.20 & 1.19 & 1.17 & 0.023 & NS & 1.01 & 1.00 & 0.95 & 0.016 & $\dagger$ \\
\hline Lactose, $\mathrm{kg} / \mathrm{d}$ & $1.42^{\mathrm{a}}$ & $1.52^{\mathrm{b}}$ & $1.47^{\mathrm{ab}}$ & 0.017 & * & 1.94 & 1.93 & 1.89 & 0.042 & NS & 1.51 & 1.50 & 1.44 & 0.017 & $\dagger$ \\
\hline Yield/DMI & 1.43 & 1.42 & 1.41 & 0.039 & NS & 1.58 & 1.54 & 1.52 & 0.030 & NS & 1.45 & 1.42 & 1.39 & 0.025 & NS \\
\hline $4 \% \mathrm{FCM} / \mathrm{DMI}$ & 1.36 & 1.29 & 1.37 & 0.045 & NS & 1.45 & 1.46 & 1.45 & 0.037 & NS & 1.32 & 1.32 & 1.27 & 0.018 & NS \\
\hline $\mathrm{MP} / \mathrm{CPI}^{4}$ & $0.34^{\mathrm{a}}$ & $0.29^{\mathrm{b}}$ & $0.27^{\mathrm{b}}$ & 0.010 & $* *$ & $0.30^{\mathrm{a}}$ & $0.30^{\mathrm{a}}$ & $0.28^{\mathrm{b}}$ & 0.005 & $*$ & 0.35 & 0.34 & 0.33 & 0.008 & NS \\
\hline OMD, $\% 5$ & 80.5 & 79.3 & 73.7 & 2.12 & NS & 79.7 & 77.5 & 79.1 & 1.72 & NS & 78.6 & 82.1 & 78.8 & 1.60 & NS \\
\hline
\end{tabular}

a,b,c Values in the same row that share a common superscript are not statistically different $(P>0.05)$.

${ }^{1}$ Diets are named according to the effective RDP:fermentable metabolizable energy ratio of the diet: RL, RM, and RH provided a large deficiency, a slight deficiency, and a slight excess, respectively.

${ }^{2}$ Diets are named according to the urea content of the concentrates: U0 $=0 \%$, U5 $=0.5 \%$, and U10 $=1.0 \%$.

${ }^{3}$ Treatments are named according to the mode of distribution of the protein-rich concentrate: DU = as a TMR with the basal diet; D2 = in two meals, immediately before the distribution of the basal diet; and D1 = in one meal, immediately before the distribution of the morning meal.

${ }^{4}$ Milk protein/CP intake.

${ }^{5} \mathrm{OMD}=\mathrm{OM}$ digestibility.

$* P<0.05$.

$* * P<0.01$.

$\dagger P<0.10$.

\section{DISCUSSION}

\section{Feed Evaluation}

The formulation objectives for Exp. 1 were to produce three isoenergetic diets that met metabolizable protein requirements, but which differed widely in ERDP:FME ratio. Application of U.K. standard equations to the results of feed analysis showed that diets were isoenergetic, in agreement with the application of NRC (2001) equations. The targets for ERDP:FME ratios were a large deficiency, a slight deficiency, and a slight excess of ERDP in relation to the AFRC (1993) target level of $11 \mathrm{~g}$ of ERDP/MJ of FME for lactating cows: 8, 10, and $12 \mathrm{~g}$ of ERDP/MJ of FME respectively. Results from the in sacco evaluation showed that although we did not achieve the ERDP/FME targets precisely, we produced diets that met the target of a slight excess, a slight deficiency, and a large deficiency. In fact, the large deficiency was usefully larger than we had predicted based on published values. The estimates of ERDP:FME ratios were further confirmed by plasma urea values, which increased with the increase on ERDP:FME ratio. In spite of the large difference in ERDP content of diets, they were all predicted to be adequate or in excess for metabolizable protein balance (AFRC, 1993). This was achieved for diet RL because of its lower CP degradability.

In Exp. 2, although the objective of isoenergetic diets was almost achieved, the calculated ERDP:FME ratio for a fixed rumen retention time of $12 \mathrm{~h}$ for diet U10 was higher than that for U0 and U5. However, this apparent discrepancy was not confirmed by differences in plasma urea concentrations. Additionally, the relatively high values for plasma urea in this experiment suggest that microbial $\mathrm{CP}$ synthesis would had been limited by FME supply. The relatively low ERDP:FME ratio of diet used in Exp. 3 agreed with the formulation aim.

\section{Feed Intake}

The reduced feed intakes that result when cows are offered low-protein diets are well recognized (Cressman et al., 1980; Christensen et al., 1993; Wu and Satter, 2000). In the current study, a diet containing $10.1 \mathrm{~g}$ of ERDP/MJ of FME was sufficient to avoid intake depression. This level of ERDP feeding is below the level (11 $\mathrm{g}$ of ERDP/MJ of FME) suggested in the U.K. system 
Table 6. Least squares means for allantoin and creatinine concentrations and allantoin/creatinine ratios $(\mathrm{A} / \mathrm{c})$ in the spot urine samples from the different dietary treatments and sampling time, and predicted microbial CP supply (MCP).

\begin{tabular}{|c|c|c|c|c|c|c|c|c|c|c|}
\hline \multirow{2}{*}{$\frac{\text { Item }}{\text { Experiment } 1}$} & \multicolumn{3}{|c|}{ Diets } & \multirow[t]{2}{*}{ SEM } & \multirow[t]{2}{*}{$P$} & \multicolumn{3}{|c|}{ Sampling time $(\mathrm{h})$} & \multirow[t]{2}{*}{ SEM } & \multirow[t]{2}{*}{$P$} \\
\hline & $\mathrm{RL}^{1}$ & $\mathrm{RM}^{1}$ & $\mathrm{RH}^{1}$ & & & 8 & 16 & 24 & & \\
\hline $\mathrm{n}$ & 23 & 24 & 24 & & & 24 & 23 & 24 & & \\
\hline Allantoin $(\mathrm{mmol} / \mathrm{L})$ & $58.1^{\mathrm{a}}$ & $41.0^{\mathrm{b}}$ & $44.4^{\mathrm{b}}$ & 4.42 & $*$ & 42.2 & 47.9 & 53.4 & 4.33 & NS \\
\hline Creatinine $(\mathrm{mmol} / \mathrm{L})$ & $14.8^{\mathrm{a}}$ & $11.0^{\mathrm{b}}$ & $11.5^{\mathrm{b}}$ & 0.97 & $*$ & 11.4 & 12.4 & 13.5 & 0.96 & NS \\
\hline $\mathrm{A} / \mathrm{c}(\mathrm{mmol} / \mathrm{mmol})$ & 3.83 & 3.69 & 3.93 & 0.130 & NS & 3.79 & 3.81 & 3.85 & 0.128 & NS \\
\hline Predicted MCP $(\mathrm{g} / \mathrm{d})^{2}$ & $1294^{\mathrm{a}}$ & $2020^{\mathrm{b}}$ & $2167^{\mathrm{c}}$ & 27.8 & $* * *$ & & & & & \\
\hline Experiment 2 & $\mathrm{U} 0^{3}$ & $\mathrm{U} 5^{3}$ & $\mathrm{U} 10^{3}$ & & & 6 & 14 & 22 & & \\
\hline $\mathrm{n}$ & 27 & 27 & 21 & & & 25 & 25 & 25 & & \\
\hline Allantoin $(\mathrm{mmol} / \mathrm{L})$ & $47.9^{\mathrm{a}}$ & $38.6^{\mathrm{b}}$ & $49.4^{\mathrm{a}}$ & 2.53 & ** & 43.6 & 48.2 & 44.1 & 2.47 & NS \\
\hline Creatinine $(\mathrm{mmol} / \mathrm{L})$ & 11.4 & 10.5 & 11.2 & 0.50 & NS & $10.0^{\mathrm{a}}$ & $12.4^{\mathrm{b}}$ & $10.6^{\mathrm{a}}$ & 0.49 & $* *$ \\
\hline $\mathrm{A} / \mathrm{c}(\mathrm{mmol} / \mathrm{mmol})$ & $4.14^{\mathrm{a}}$ & $3.70^{\mathrm{b}}$ & $4.40^{\mathrm{a}}$ & 0.118 & $* * *$ & $4.28^{\mathrm{a}}$ & $3.84^{\mathrm{b}}$ & $4.12^{\mathrm{ab}}$ & 0.116 & $*$ \\
\hline Predicted MCP $(\mathrm{g} / \mathrm{d})^{2}$ & $2403^{\mathrm{a}}$ & $2459^{\mathrm{a}}$ & $2690^{\mathrm{b}}$ & 30.5 & $* * *$ & & & & & \\
\hline Experiment 3 & $\mathrm{DU}^{4}$ & $\mathrm{D} 2^{4}$ & $\mathrm{D} 1^{4}$ & & & 6 & 14 & 22 & & \\
\hline $\mathrm{n}$ & 21 & 21 & 21 & & & 21 & 21 & 21 & & \\
\hline Allantoin $(\mathrm{mmol} / \mathrm{L})$ & 69.0 & 59.2 & 53.3 & 5.77 & NS & 54.7 & 64.8 & 62.1 & 5.11 & NS \\
\hline Creatinine $(\mathrm{mmol} / \mathrm{L})$ & $18.7^{\mathrm{a}}$ & $14.6^{\mathrm{ab}}$ & $13.8^{\mathrm{b}}$ & 1.37 & $*$ & $12.2^{\mathrm{a}}$ & $17.7^{\mathrm{b}}$ & $17.2^{\mathrm{b}}$ & 1.21 & $* *$ \\
\hline $\mathrm{A} / \mathrm{c}(\mathrm{mmol} / \mathrm{mmol})$ & 3.98 & 4.00 & 3.91 & 0.213 & NS & $4.37^{\mathrm{a}}$ & $3.80^{\mathrm{b}}$ & $3.72^{\mathrm{b}}$ & 0.189 & $*$ \\
\hline Predicted MCP $(\mathrm{g} / \mathrm{d})^{2}$ & 1804 & 1838 & 1793 & 20.0 & NS & & & & & \\
\hline
\end{tabular}

a,b,c Values in the same row that share a common superscript are not statistically different $(P>0.05)$.

${ }^{1}$ Diets are named according to the effective RDP:fermentable metabolizable energy ratio of the diet: RL, $\mathrm{RM}$, and RH provided a large deficiency, a slight deficiency, and a slight excess, respectively.

${ }^{2}$ Calculated based on actual intake, according to AFRC (1993) for a mean rumen retention time of $12 \mathrm{~h}$.

${ }^{3}$ Diets are named according to the urea content of the concentrates: U0 $=0 \%$, U5 $=0.5 \%$, and U10 $=1.0 \%$.

${ }^{4}$ Treatments are named according to the mode of distribution of the protein-rich concentrate: DU $=$ as a TMR with the basal diet; D2 = in two meals, immediately before the distribution of the basal diet; and D1 $=$ in one meal, immediately before the distribution of the a.m. meal.

$* P<0.05$.

$* * P<0.01$.

$* * * P<0.001$.

(AFRC, 1993) for lactating dairy cows. The CP content of diets used in Exp. 1 increased in line with increasing ERDP:FME, and it is often difficult to distinguish whether cows are responding to RDP (Roffler and Satter, 1975) or both RDP and RUP (Kalscheur et al., 1999). In this study, the marked decline in feed intake with $\operatorname{diet} \mathrm{RL}$ suggests that the rumen microbes were restricted by lack of ERDP, in agreement with some earlier studies (Dhiman and Satter, 1993; Weigel et al., 1997). The CP content of the RM diet (15.7\% of DM) was below levels that are often used in practice, but feeding additional protein $(\mathrm{RH})$ did not result in any additional milk protein yield, so the efficiency of feed $\mathrm{N}$ declined. This result demonstrates the potential to develop feeding strategies that reduce $\mathrm{N}$ excretion in feces and urine without compromising milk yields.

The type and amount of energy available for microbial fermentation (Hoover and Stokes, 1991), as well types of protein (Erasmus et al., 1994) and the synchrony of energy and $\mathrm{N}$ supply to the rumen (Shabi et al., 1998), should also be considered in interpreting the responses to dietary $\mathrm{CP}$ content. Altering the synchrony of energy and $\mathrm{N}$ supply to rumen microbes by changing feeds (to alter the QDP:SDP ratio; Exp. 2) or by altering meal patterns of protein-rich concentrate (Exp. 3) did not affect DMI. This may have been the consequence of the high levels of nonstructural carbohydrate in these diets (Jaquette et al., 1987).

Dawson (1999) postulated that ruminants could detect asynchrony in the rate of supply of nutrients in the rumen. She further speculated that cows have developed mechanisms to overcome or minimize its effects, by altering their pattern of feed intake to avoid an excessive load of ammonia, storing carbohydrates by rumen microbes during periods of $\mathrm{N}$ deficit, and by higher recycling of urea to the rumen. The highly significant treatment $\times$ sampling time interaction effect on plasma urea concentration (Table 7) confirms our success in generating different patterns of $\mathrm{N}$ intake between the three treatment groups. The cows were not successful in overcoming the imposed manipulations of synchrony. Diet D1 represent a much greater degree of asynchrony than might be observed in practice, at least with diets based on corn silage. The relatively low CP content of the diets used in Exp. 3 also provides the maximal opportunity for us to identify effects of rumen synchrony since rumen effects would not be masked by excess RUP. Whereas grass silage has an extremely 
Table 7. Least squares means for plasma concentrations of glucose, urea, albumin, and total proteins from the different dietary treatments.

\begin{tabular}{|c|c|c|c|c|c|c|}
\hline & $\mathrm{n}$ & $\begin{array}{l}\text { Sampling } \\
\text { time }\end{array}$ & $\begin{array}{l}\text { Glucose, } \\
\mathrm{mg} / \mathrm{dl}\end{array}$ & $\begin{array}{l}\text { Urea, } \\
\mathrm{mg} / \mathrm{dl}\end{array}$ & $\begin{array}{l}\text { Albumin, } \\
\text { g/dl }\end{array}$ & $\begin{array}{l}\text { Total } \\
\text { proteins, } \\
\text { g/dl }\end{array}$ \\
\hline \multicolumn{7}{|l|}{ Experiment 1} \\
\hline $\mathrm{RL}^{1}$ & 8 & & 53.5 & $23.3^{\mathrm{a}}$ & 3.20 & 8.13 \\
\hline $\mathrm{RM}^{1}$ & 8 & & 51.7 & $30.0^{\mathrm{b}}$ & 3.28 & 7.80 \\
\hline $\mathrm{RH}^{1}$ & 8 & & 55.1 & $36.5^{\mathrm{c}}$ & 3.22 & 8.05 \\
\hline SEM & & & 1.20 & 1.06 & 0.073 & 0.118 \\
\hline$P$ & & & NS & $* * *$ & NS & NS \\
\hline \multicolumn{7}{|l|}{ Experiment 2} \\
\hline $\mathrm{U}^{2}$ & 9 & & 62.3 & 37.9 & 3.59 & 7.70 \\
\hline $\mathrm{U} 5^{2}$ & 9 & & 64.6 & 37.6 & 3.87 & 7.45 \\
\hline $\mathrm{U} 10^{2}$ & 7 & & 63.1 & 39.1 & 3.75 & 7.46 \\
\hline SEM & & & 1.47 & 1.26 & 0.105 & 0.156 \\
\hline$P$ & & & NS & NS & NS & NS \\
\hline \multicolumn{7}{|l|}{ Experiment $3^{3}$} \\
\hline \multirow[t]{2}{*}{$\mathrm{DU}^{4}$} & 7 & Before & 68.0 & $28.6^{\mathrm{a}}$ & 3.69 & 7.47 \\
\hline & 7 & After & 59.4 & $31.5^{\mathrm{ab}}$ & 3.61 & 7.27 \\
\hline \multirow[t]{2}{*}{$\mathrm{D} 2^{4}$} & 7 & Before & 68.8 & $25.1^{\mathrm{c}}$ & 3.65 & 7.35 \\
\hline & 7 & After & 57.8 & $33.5^{\text {bd }}$ & 3.62 & 7.30 \\
\hline \multirow[t]{2}{*}{$\mathrm{D} 1^{4}$} & 7 & Before & 65.5 & $23.4^{\mathrm{c}}$ & 3.67 & 7.58 \\
\hline & 7 & After & 61.3 & $35.3^{\mathrm{d}}$ & 3.64 & 7.51 \\
\hline SEM & & & 2.2 & 1.09 & 0.034 & 0.086 \\
\hline \multicolumn{7}{|l|}{ Effects } \\
\hline Treatment & & & NS & NS & NS & $\dagger$ \\
\hline Sampling time & & & **** & $* * *$ & $\dagger$ & NS \\
\hline Treatment $\times$ sampling time & & & NS & $* * *$ & NS & NS \\
\hline \multicolumn{7}{|c|}{ a,b,c,d Values in the same column that share a common superscript are not statistically different $(P>0.05)$. } \\
\hline \multicolumn{7}{|c|}{$\begin{array}{l}{ }^{1} \text { Diets are named according to the effective RDP:fermentable metabolizable energy ratio of the diet: RL, } \\
\text { RM, and RH provided a large deficiency, a slight deficiency, and a slight excess, respectively. }\end{array}$} \\
\hline \multirow{2}{*}{\multicolumn{7}{|c|}{$\begin{array}{l}{ }^{2} \text { Diets are named according to the urea content of the concentrates: } \mathrm{U} 0=0 \% \text {, U5 }=0.5 \% \text {, and U10 }=1.0 \% \text {. } \\
{ }^{3} \text { Interaction of treatment } \times \text { sampling time for urea }(P<0.001) \text {. }\end{array}$}} \\
\hline & & & & & & \\
\hline \multicolumn{7}{|c|}{${ }^{4}$ Treatments are named according to the mode of distribution of the protein-rich concentrate: $\mathrm{DU}=\mathrm{as}$ a } \\
\hline \multirow{2}{*}{\multicolumn{7}{|c|}{$\begin{array}{l}\text { TMR with the basal diet; } \mathrm{D} 2=\text { in two meals, immediately before the distribution of the basal diet; and D1 } \\
=\text { in one meal, immediately before the distribution of the morning meal. } \\
*_{* *} P<0.001 \text {. }\end{array}$}} \\
\hline & & & & & & \\
\hline$\dagger P<0.10$. & & & & & & \\
\hline
\end{tabular}

asynchronous supply of RDP and energy, it has a much higher $\mathrm{CP}$ content than corn silage; therefore, it is difficult to envisage practical diets and feeding situations in which rumen synchrony is an important factor affecting performance. Despite the extreme nature of diet D1, there was only a small and nonsignificant reduction in $\mathrm{N}$ use efficiency.

\section{Urinary Allantoin and Creatinine Excretion}

Several studies have shown that water intake (Silanikove et al., 1997; Dinn et al., 1998) and urine output (Holter and Urban, 1992; Moscardini et al., 1998) increase as the amount of excess $\mathrm{N}$ that has to be excreted increases. This effect results from the diuretic effect of increased protein intake (Broderick et al., 1974) and from a progressive increase in $\mathrm{N}$ that exceeds the capacity of the kidneys to concentrate urea that is mediated by changes in the glomerular filtration rate (Eriksson and Valtonen, 1982). In the present study, the highest mean allantoin and creatinine concentrations were observed with the low-CP diets (RL, DU, D2, and D1). Overall, there was a significant negative correlation between allantoin and creatinine concentrations in urine and diet $\mathrm{CP}(\mathrm{r}=-0.346, P<0.01$ and $\mathrm{r}=-0.441$, $P<0.001$ for allantoin and creatinine concentrations, respectively). Allantoin and creatinine concentrations also increased with increasing rumen synchrony in Exp. 3 , perhaps as a result of the reduced requirement to eliminate urea. The effects of protein supply and synchrony on water intakes, and consequent rumen outflow rates, will complicate the interpretation of factors affecting $\mathrm{N}$ utilization.

The urinary $\mathrm{A} / \mathrm{c}$ technique did not identify any consistent differences in microbial protein yield, predicted according to AFRC (1993), within the experiments, despite the observed differences in DMI and milk yields. Although these experiments were Latin square designs, and urine was collected from each cow three times daily over 2 consecutive days, the $\mathrm{A} / \mathrm{c}$ ratio in urine spot 
samples did not reflect the predicted effect of diets on microbial protein supply (Table 6). In fact, earlier results indicate that microbial $\mathrm{N}$ flow must be altered by approximately $84 \mathrm{~g} / \mathrm{d}$ before the amount of allantoin excreted in the urine reflects changes in microbial $\mathrm{N}$ flow (Johnson et al., 1998). There are a number of possible reasons for imprecision in the urinary $\mathrm{A} / \mathrm{c}$ technique, including effects of tissue catabolism (Nsahlai et al., 2000 ), variation in creatinine excretion with diet and between cow, and diurnal variations in allantoin and creatinine excretion (Shingfield and Offer, 1998). In the experiments reported here, we also found significant diurnal variation in urinary creatinine concentration (Table 6), and it is likely that diet could have had a significant effect on creatinine excretion. Therefore, the data presented are consistent with the statement of Shingfield and Offer (1998) that total urine collection appears necessary to assess accurately urinary purine derivative excretion in dairy cows. In their studies, even an intensive urine-sampling regimen (every $2 \mathrm{~h}$ ) did not allow an acceptable prediction of daily mean $\mathrm{A} /$ c ratio.

\section{Milk Production and Composition}

As expected, the lower DMI with RL diet reduced milk production. However, this low-protein diet also resulted in the most efficient conversion of dietary $\mathrm{CP}$ intake into milk protein. Wu and Satter (2000) also obtained the highest efficiency for converting dietary $\mathrm{N}$ into milk $\mathrm{N}$ with the lowest protein treatment (15.4 to $16 \% \mathrm{CP}$ ), which was clearly deficient in protein.

Altering dietary protein degradability (Exp. 2) did not affect milk production. These results are consistent with those obtained by Christensen et al. (1993) who fed dairy cows a TMR containing either 16.4 or $19.4 \%$ $\mathrm{CP}$ with a ruminal CP degradability of 55 or $70 \%$. The efficiency of conversion of CP intake into milk protein was significantly affected by dietary treatment, with the lowest value for cows that received the high-urea $\operatorname{diet}(\mathrm{U} 10)$, reflecting the highest CP content of diet U10 (Table 3).

Studies have shown that diets formulated to have more synchronized release of $\mathrm{N}$ and energy-yielding nutrients in the rumen significantly increase microbial protein synthesis and efficiency (Herrera-Saldana et al., 1990; Aldrich et al., 1993). In order to avoid confounding effects of different ingredient feeds, only the feeding pattern of the protein concentrate was altered in Exp. 3, and although dietary treatments did not significantly affect DMI, milk production was significantly lower with the less synchronized diet. Conversely, Kolver et al. (1998), who simply altered the time of feeding concentrates, demonstrated that the synchro- nous diet promoted consistently lower ruminal ammonia concentrations but had no significant effect on milk production. However, if the frequency of feeding the whole diet or of the readily fermentable carbohydrate is altered, there are often pronounced effects on ruminal $\mathrm{pH}$ and the composition of VFA. Since these factors may influence microbial growth, it is suggested that altering the pattern of feeding the high-protein component of diets, while all other components of the diet are kept constant, is the fairest test of the rumen synchrony hypothesis (Chamberlain and Choung, 1995). Robinson et al. $(1997 ; 2002)$ highlighted an additional factor that must be considered when manipulating meal patterns. They showed that rumen conditions and rumen degradation varied according to whether a protein supplement was given at night or during the day. These effects were attributed to diurnal variation in rumen fill and passage rates. Overall, the results reported here are in agreement with the statement of Chamberlain and Choung (1995) that a close matching of energy and $\mathrm{N}$ release will bring only a minor (if any) benefit in most practical conditions.

\section{CONCLUSIONS}

The results of the present study demonstrate that diets with low RDP:FME ratios restrict DMI and milk yield. Conversely, supplying RDP in excess of the amount necessary to match the amount of FME supplied by the diet and utilizable by rumen microbes did not increase DMI or milk yield in midlactation dairy cows and increased blood urea, leading to RDP waste and potential environmental pollution. It was also demonstrated that NPN could replace part of the vegetable protein in the diet without adverse effects on earlylactation dairy cow productivity as long as the supply of readily available carbohydrate was guaranteed. Providing more synchronized $\mathrm{N}$ and energy supply for the rumen microbes to midlactation dairy cows led to higher milk yields, due perhaps to increased microbial protein synthesis. However, these effects were only observed with extreme diets and feeding strategies, and it is concluded that attempts to match energy and $\mathrm{N}$ release in the rumen will not bring additional benefits in practical feeding conditions. Urinary output increased in response to increased or unbalanced protein supply. Analysis of the $\mathrm{A} / \mathrm{c}$ ratio in spot samples of urine was not useful in identifying differences in microbial protein yield from the rumen.

\section{ACKNOWLEDGMENTS}

The authors are grateful for the help of the staff of Dairy Unit of Direcção Regional de Agricultura do En- 
tre-Douro e Minho for the care of animals and analysis of milk samples. We also acknowledge the assistance of the nutrition laboratory of AGROS/Universidade do Porto and the Ruminant Nutrition laboratory of IGER in the analysis of feed and urine samples, respectively, and of SODOL-Sociedade Descascadora Ovarense, Ltd., Ovar, Portugal, which produced the concentrates. A. R. J. Cabrita gratefully acknowledges the receipt of a scholarship from Ministério da Ciência e Tecnologia of Portugal (Grant PRAXIS XXI/BD/21331/99).

\section{REFERENCES}

AFRC. 1993. Energy and Protein Requirements of Ruminants. Agricultural and Food Research Council. CAB Int., Wallingford, Oxon, U.K.

Aldrich, J. M., L. D. Muller, G. A. Varga, and L. C. Griel, Jr. 1993. Nonstructural carbohydrate and protein effects on rumen fermentation, nutrient flow, and performance of dairy cows. J. Dairy Sci. 76:1091-1105.

AOAC. 1990. Official Methods of Analysis. Vol. I. 15th ed. Assoc. Offic. Anal. Chem., Arlington, VA.

Bauer, J. D. 1982. Clinical Laboratory Methods. 9th ed. D. Ladig, ed. The C. V. Mosby Co., St. Louis, MO.

Broderick, G. A., L. D. Satter, and A. E. Harper. 1974. Use of plasma amino acid concentration to identify limiting amino acids for milk production. J. Dairy Sci. 57:1015-1023.

Casper, D. P., H. A. Maiga, M. J. Brouk, and D. J. Schingoethe. 1999. Synchronization of carbohydrate and protein sources on fermentation and passage rates in dairy cows. J. Dairy Sci. 82:1779-1790.

Chamberlain, D. G., and J.-J. Choung. 1995. The importance of rate of ruminal fermentation of energy sources in diets for dairy cows. Pages 67'89 in Recent Advances in Animal Nutrition. P. C. Garnsworthy and D. J. A. Cole, ed. Nottingham Univ. Press, Nottingham, U.K.

Chen, X. B., F. D. D. Hovell, E. R. Ørskov, and D. S. Brown. 1990. Excretion of purine derivatives by ruminants: Effect of exogenous nucleic acid supply on purine derivative excretion by sheep. $\mathrm{Br}$. J. Nutr. 63:131-142.

Christensen, R. A., G. L. Lynch, J. H. Clark, and Y. Yu. 1993. Influence of amount and degradability of protein on production of milk and milk components by lactating Holstein cows. J. Dairy Sci. 76:3490-3496.

Cressman, S. G., D. G. Grieve, G. K. Macleod, E. E. Wheeler, and L. G. Young. 1980. Influence of dietary protein concentration on milk production by dairy cattle in early lactation. J. Dairy Sci. 63:1839-1847.

Dawson, J. M. 1999. Variation in nutrient supply and effects on whole body anabolism. G. E. Lobley, A. White, and J. C. MacRae, ed. Pages 101-126 in Proc. 8th Int. Symp. on Protein Metabol. and Nutr. EAAP Publ. No. 96, Aberdeen, U.K.

De Groot, T. H., and J. H. Aafjes. 1960. On the constancy of creatinine excretion in the urine of the dairy cow. Br. Vet. J. 116:409-418.

Dewhurst, R. J., D. R. Davies, and R. J. Merry. 2000. Microbial protein supply from the rumen. Anim. Feed Sci. Technol. 85:1-21.

Dewhurst, R. J., R. T. Evans, T. T. Mottram, P. Spanel, and D. Smith. 2001. Assessment of rumen processes by selected-ion-flow-tube mass spectrometric analysis of rumen gases. J. Dairy Sci. 84:1438-1444.

Dewhurst, R. J., A. M. Mitton, N. W. Offer, and C. Thomas. 1996. Effects of the composition of grass silages on milk production and nitrogen utilization by dairy cows. Anim. Sci. 62:25-34.

Dhiman, T. R., and L. D. Satter. 1993. Protein as the first-limiting nutrient for lactating dairy cows fed high proportions of good quality alfalfa silage. J. Dairy Sci. 76:1960-1971.

Dinn, N. E., J. A. Shelford, and L. J. Fisher. 1998. Use of the Cornell Net Carbohydrate and protein system and rumen-protected lysine and methionine to reduce nitrogen excretion from lactating dairy cows. J. Dairy Sci. 81:229-237.

Erasmus, L. J., P. M. Botha, and H. H. Meissner. 1994. Effect of protein source on ruminal fermentation and passage of amino acids to the small intestine of lactating cows. J. Dairy Sci. 77:3655-3665.

Eriksson, L., and M. Valtonen. 1982. Renal urea handling in goats fed high and low protein diets. J. Dairy Sci. 65:385-389.

Givens, D. I. 1990. The digestibility of maize silage-An update. Proc. 2nd Annu. Conf. of the Maize Growers Assoc., Reading, U.K.

Herrera-Saldana, R., R. Gomez-Alarcon, M. Torabi, and J. T. Huber. 1990. Influence of synchronizing protein and starch degradation in the rumen on nutrient utilization and microbial protein synthesis. J. Dairy Sci. 73:142-148.

Holter, J. B., and W. E. Urban, Jr. 1992. Water partitioning and intake prediction in dry and lactating Holstein cows. J. Dairy Sci. 75:1472-1479.

Hoover, W. H., and S. R. Stokes. 1991. Balancing carbohydrates and proteins for optimum rumen microbial yield. J. Dairy Sci. 74:3630-3644.

Jaquette, R. D., A. H. Rakes, and W. J. Croom, Jr. 1987. Effect of amount and source of dietary nitrogen on milk fat depression in early lactation dairy cows. J. Dairy Sci. 70:1202-1210.

Johnson, L. M., J. H. Harrison, and R. E. Riley. 1998. Estimation of the flow of microbial nitrogen to the duodenum using urinary uric acid or allantoin. J. Dairy Sci. 81:2408-2420.

Kalscheur, K. F., J. H. Vandersall, R. A. Erdman, R. A. Kohn, and E. Russek-Cohen. 1999. Effects of dietary crude protein concentration and degradability on milk production responses of early, mid, and late lactation dairy cows. J. Dairy Sci. 82:545-554.

Kolver, E., L. D. Muller, G. A. Varga, and T. J. Cassidy. 1998. Synchronization of ruminal degradation of supplemental carbohydrate with pasture nitrogen in lactating dairy cows. J. Dairy Sci. 81:2017-2028.

Mabjeesh, S. J., A. Arieli, I. Bruckental, S. Zamwell, and H. Tagari. 1997. Effect of ruminal degradability of crude protein and nonstructural carbohydrates on the efficiency of bacterial crude protein synthesis and amino acid flow to the abomasum of dairy cows. J. Dairy Sci. 80:2939-2949.

McAllan, A. B. 1982. The fate of nucleic acids in ruminants. Proc. Nutr. Soc. 41:309-317.

McCormick, M. E., D. D. French, T. F. Brown, G. J. Cuomo, A. M. Chapa, J. M. Fernandez, J. F. Beatty, and D. C. Blouin. 1999. Crude protein and rumen undegradable protein effects on reproduction and lactation performance of Holstein cows. J. Dairy Sci. 82:2697-2708.

Ministry of Agriculture, Fisheries and Food. 1986. The Analysis of Agricultural Materials. HMSO, London, U.K.

Moscardini, S., T. C. Wright, P. H. Luimes, B. W. McBride, and P. Susmel. 1998. Effects of rumen-undegradable protein and feed intake on purine derivative and urea nitrogen: Comparison with predictions from the Cornell Net Carbohydrate and Protein system. J. Dairy Sci. 81:2421-2429.

Moss, A. R., and Givens D. I. 1990. Chemical composition and in vitro digestion to predict digestibility of field-cured and barndried grass hays. Anim. Feed. Sci. Technol. 31:125-138.

Norma Portuguesa 1786. 1985. Alimentos para animais, determinação do teor de cálcio, método volumétrico, processo corrente. Diário da República, III Série de 09/07, No. 155.

Norma Portuguesa 2971. 1985. Alimentos para animais, determinação do teor de cinza insolúvel no ácido clorídrico. Diário da República, III Série de 10/11, No. 260.

Norma Portuguesa 1785. 1986. Determinação do teor de açúcares. Diário da República, III Série de 30/05, No. 123.

Norma Portuguesa 3255. 1986. Determinação do teor de ureia. Método espectrofotométrico. Diário da República, III Série de 30/05, No. 123

Norma Portuguesa 873. 1997. Alimentos para animais, determinação do teor de fósforo, método gravimétrico. Diário da República, III Sërie de 04/05, No. 103.

NRC. 2001. Nutrient Requirements of Dairy Cattle. 7th ed. Natl. Acad. Press, Washington, DC. 
Nsahlai, I. V., P. O. Osuji, and N. N. Umunna. 2000. Effect of form and of quality of feed on the concentrations of purine derivatives in urinary spot samples, daily microbial $\mathrm{N}$ supply and predictability of intake. Anim. Feed Sci. Technol. 85:223-238.

Ørskov, E. R., F. D. D. Hovell, and F. Mould. 1980. The use of nylon bag technique for the evaluation of feedstuffs. Trop. Anim. Prod. $5: 195-213$.

Robertson, J. B., and P. J. Van Soest. 1981. The Detergent System of Analysis and Its Application in Human Foods. W. P. T. James and O. Theander, ed. Marcell Dekker, Inc., New York, NY.

Robinson, P. H., M. Gill, and J. J. Kennelly. 1997. Influence of time of feeding a protein meal on ruminal fermentation and forestomach digestion in dairy cows. J. Dairy Sci. 80:1366-1373.

Robinson, P. H., M. Gill, and J. J. Kennelly. 2002. Influence of time of feeding a protein meal on diurnal patterns of amino acids in duodenal digesta protein of lactating dairy cows. Anim. Feed Sci. Technol. 97:115-121.

Roffler, R. E., and L. D. Satter. 1975. Relationship between ruminal ammonia and nonprotein nitrogen utilization by ruminants. II. Application of published evidence to the development of a theoretical model for predicting nonprotein nitrogen utilization. J. Dairy Sci. 58:1889-1898.

Shabi, Z., A. Arieli, I. Bruckental, Y. Aharoni, S. Zamwel, A. Bor, and H. Tagari. 1998. Effect of the synchronization of the degradation of dietary crude protein and organic matter and feeding frequency on ruminal fermentation and flow of digesta in the abomasum of dairy cows. J. Dairy Sci. 81:1991-2000.
Shingfield, K. J., and N. W. Offer. 1998. Evaluation of milk allantoin excretion as an index of microbial protein supply in lactating dairy cows. Anim. Sci. 67:371-385.

Silanikove, N., E. Maltz, A. Halevi, and D. Shinder. 1997. Metabolism of water, sodium, potassium, and chlorine by high yielding dairy cows at the onset of lactation. J. Dairy Sci. 80:949-956.

Solomonson, A., A. Theander, and E. Westerlund. 1984. Chemical characterization of some cereal whole meal and bran fractions. Swedish J. Agric. Res. 14:111-117.

Steel, R. G. D., and J. H. Torrie. 1980. Principles and Procedures of Statistics: A Biometrical Approach. 2nd ed., McGraw-Hill Book Co., New York, NY.

Tamminga, S. 1992. Nutrition management of dairy cows as a contribution to pollution control. J. Dairy Sci. 75:345-357.

Thomas, P. C., S. Robertson, D. G. Chamberlain, R. M. Livingstone, P. H. Garthwaite, P. J. S. Dewey, R. Smart, and C. Whyte. 1988. Predicting the metabolizable energy (ME) content of compounded feeds for ruminants. Pages 127-146 in Recent Advances in Animal Nutrition. W. Haresign and D. J. A. Cole, ed. Butterworths, London, U.K.

Weigel, D. J., J. P. Elliott, and J. H. Clark. 1997. Effects of amount and ruminal degradability of protein on nutrient digestibility and production by cows fed tallow. J. Dairy Sci. 80:1150-1159.

Wu, Z., and L. D. Satter. 2000. Milk production during the complete lactation of dairy cows fed diets containing different amounts of protein. J. Dairy Sci. 83:1042-1051. 